MiA Žustra

PolYGLOTTE INSTITUTE D.O.O.

ZAGREB, HRVATSKa

mzustra@gmail.com

https://doi.org/10.17234/9789531755139.36

\title{
SEMANTIČKA ANALIZA ANIMALISTIČKIH POREDBENIH FRAZEMA SA ZNAČENJEM MRŠAVOSTI, VITKOSTI I DEBLJINE U RUSKOM I HRVATSKOM JEZIKU
}

\begin{abstract}
U ovom će se radu provesti semantička analiza animalističkih poredbenih frazema kojima se u ruskome i hrvatskome standardnom jeziku ukazuje na čovjekovu mršavost, vitkost i debljinu. Najprije će se spomenuti opće karakteristike poredbenih frazema, zatim odrediti najzastupljeniji strukturni tipovi animalističkih poredbenih frazema koji ulaze u koncept mršavosti, vitkosti i debljine, nakon čega će uslijediti njihova značenjska analiza. Unutar svakoga od spomenutih koncepata frazemi će biti raspoređeni prema životinjskome razredu kojemu pripada animalizam u njihovu sastavu, počevši od najprimitivnijih prema složenijima. Svaki će primjer biti popraćen komentarom o njegovu značenju i konotaciji koju nosi.
\end{abstract}

Ključne riječi: ruski i hrvatski jezik, poredbeni frazem, animalizam, mršavost, debljina

\section{Uvod}

Poredbeni frazemi zauzimaju znatan dio sveukupnoga frazeološkog korpusa u većini jezika, stoga se nerijetko proučavaju zasebno. Kao što i samo ime govori, u poredbenim se frazemima jedan pojam uspoređuje s drugim, najčešće na temelju sličnosti ili asocijacije. Takav princip u velikoj mjeri izoštrava sliku pojma o kojemu je riječ, čineći pritom diskurs življim i ekspresivnijim (Fink 2002:10).

U narednim poglavljima posvetit ćemo se strukturnoj i semantičkoj analizi poredbenih frazema u čijem se sastavu nalazi animalizam, a predstavljaju koncepte mršavosti, vitkosti i debljine. S lijeve će strane biti prikazani frazemi iz ruskog jezika, a s desne iz hrvatskoga. Najprije se polazi od koncepta mršavosti, nakon čega slijede frazemi koji se odnose na vitkost, a zatim na debljinu.

Redoslijed frazema unutar sva tri koncepta uvjetovan je animalizmom u njihovu sastavu. Najprije će biti navedeni frazemi koji sadrže naziv jednostavnije životinjske vrste, a zatim oni sa složenijima, pri čemu će se značenjski ekvivalenti frazema u oba jezika navesti u istome redu.

Svi frazemi koji ulaze u korpus ovoga rada pripadaju standardnom jeziku, a glavni kriterij pri odabiru frazema u oba je jezika bila njihova fiksiranost u rječnicima, a tek zatim njihova frekventnost u različitim funkcionalnim stilovima i živoj riječi, što je $i$ razlog zbog kojega neki od navedenih frazema postupno prelaze u pasivni fond. 


\section{Strukturni tipovi animalističkih poredbenih frazema}

Sa strukturnog aspekta frazemi se dijele u tri skupine - fonetske riječi, skupove riječi i rečenice. Budući da su u središtu ovoga rada poredbeni frazemi, u ovom ćemo se poglavlju posvetiti isključivo njihovim strukturnim posebitostima.

Dva su strukturna tipa poredbenih frazema: trodijelni $(A+B+C)$ i dvodijelni $(B+C)$. Komponenta A predstavlja pojam koji se s nečim uspoređuje, komponenta $\mathrm{C}$ pojam s kojim se nešto uspoređuje, a komponenta $\mathrm{B}$ sponu između njih u obliku poredbenog veznika. Zahvaljujući ustaljenosti frazema ili očitosti frazeološke slike, komponenta A nije uvijek neophodna. Takav je slučaj dvodijelnih frazema (Fink 2002:12).

Među animalističkim poredbenim frazemima koji ukazuju na koncepte mršavosti, vitkosti i debljine nailazimo isključivo na strukturni tip skupa riječi.

Prema sintaktički glavnoj riječi zabilježena su tri strukturna podtipa skupa riječi: imenički, glagolski i pridjevski, pri čemu je potonji najbrojniji. Točan broj frazema unutar sve tri skupine prikazan je na Ilustraciji 1.

Ilustracija 1. Broj animalističkih frazema sa strukturom skupa riječi unutar koncepata mršavosti, vitkosti i debljine u ruskom i hrvatskom jeziku

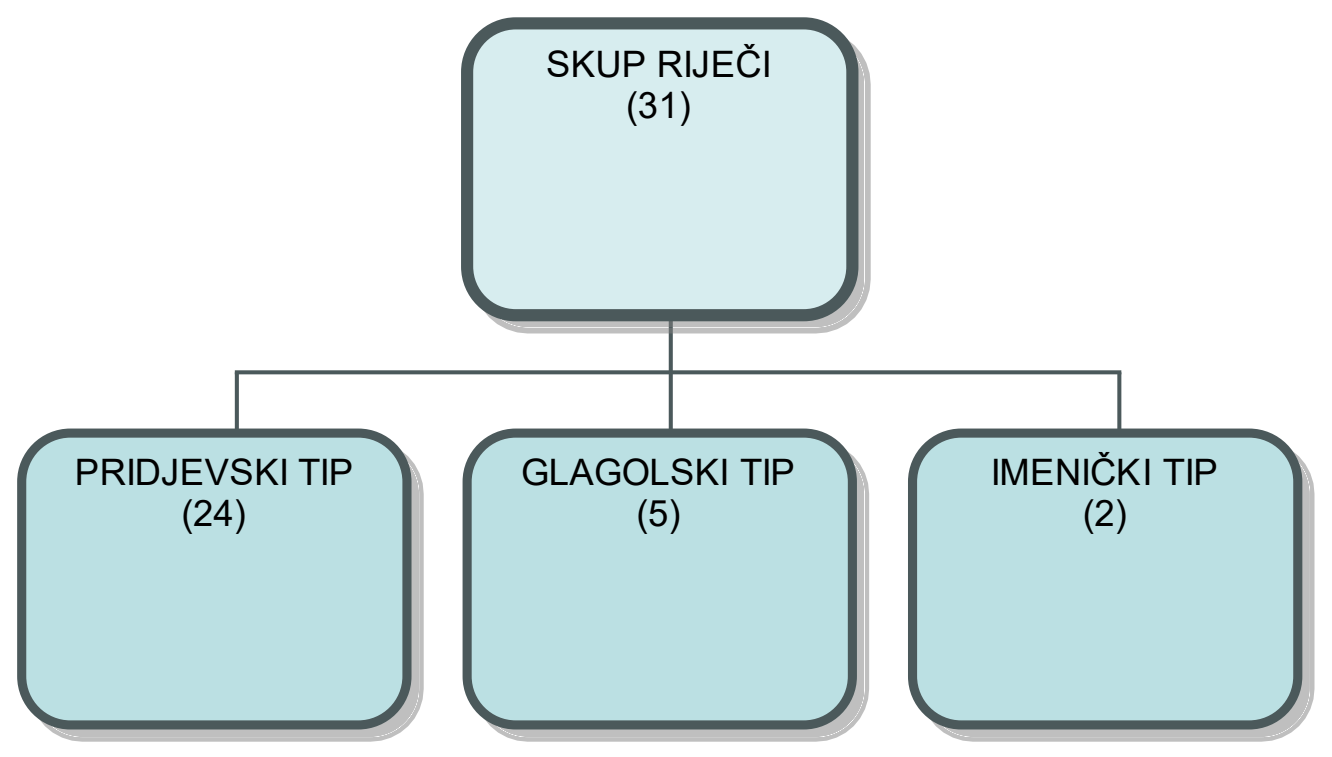

\subsection{Pridjevski tip}

Kao što je već spomenuto, najveći broj animalističkih poredbenih frazema pripada ovoj skupini. Pridjevski su frazemi zastupljeni unutar sva tri koncepta, a u korpusu su pronađene sljedeće strukturne varijante: 
a) pridjev + poredbeni veznik + imenica

худой (сухой) как вобла

худая как селёдка

худой (тощий) как глиста

mršav (suh) kao bakalar suh kao štuka mršav kao glista

худой (слабый) как воробей (воробышек, воробушек)

$<$ худая> как выдра

стройная как серна mršav kao pas жирный как каплун vitka kao srna толстый как боров debeo kao krme толстый (жирный) как кабан толстый как поросёнок толстый как свинья mršav (suh) kao komarac толетьй как свинья

b) pridjev + poredbeni veznik + pridjev + imenica худая как драная кошка худой как уличная (бездомная) собака

c) pridjev + poredbeni veznik + imenica + prijedlog + imenica + broj тощий как цыплёнок за рубль семьдесять пять

\subsection{Glagolski tip}

Ovaj je tip frazema zabilježen u oba jezika. Prva dva primjera ukazuju na mršavost, a ostali na debljinu, no svi imaju jednaku strukturu:

a) glagol + poredbeni veznik + imenica

высохнуть как вобла

разъесться (растолстеть) как боров

osušiti se kao bakalar udebljati se (utoviti se) kao prasac (prase) udebljati se (utoviti se) kao svinja

\subsection{Imenički tip}

Navedeni tip frazema nalazimo isključivo unutar koncepta debljine i to samo u ruskim primjerima, a njegova je struktura sljedeća:

a) imenica + poredbeni veznik + prijedlog + imenica щёки как у хомяка у кого

b) imenica + poredbeni veznik + prijedlog + pridjev + imenica зад как у ломовой лошади у кого 


\section{Semantička analiza animalističkih poredbenih frazema}

\subsection{Komponenta $A$}

Komponenta A predstavlja pojam koji se u frazemu uspoređuje s nekim drugim pojmom. U prethodnom smo poglavlju vidjeli da se u ulozi komponente A u animalističkim poredbenim frazemima sa značenjem mršavosti, vitkosti i debljine najčešće pojavljuje pridjev, zatim glagol, a naposljetku imenica. U nastavku slijedi prikaz najzastupljenijih pojmova koji se u prikupljenom korpusu pojavljuju u ulozi komponente A unutar sva tri koncepta.

\subsubsection{Komponenta $A$ - mršavost}

Unutar koncepta mršavosti u ruskom se jeziku u ulozi komponente A najčešće pojavljuje pridjev xyдoŭ. Međutim, postoje i frazemi u kojima on može biti zamijenjen bliskoznačnim pridjevima сухой, слабый і тощий, koji pritom ne mijenjaju njegovo značenje.

Kanonski je oblik pridjeva u većini frazema u muškome rodu, premda se dio njih odnosi isključivo na muškarca (mršav (suh) kao komarac), a dio na oba spola (mršav (suh) kao bakalar). Jedina je iznimka frazem худая как селёдка, u kojem se pridjev navodi u ženskom rodu, budući da se odnosi isključivo na ženu i to onu bez izraženih oblina. Brojnost primjera s navedenim komponentama A u ruskim frazemima prikazana je na Ilustraciji $2^{1}$.

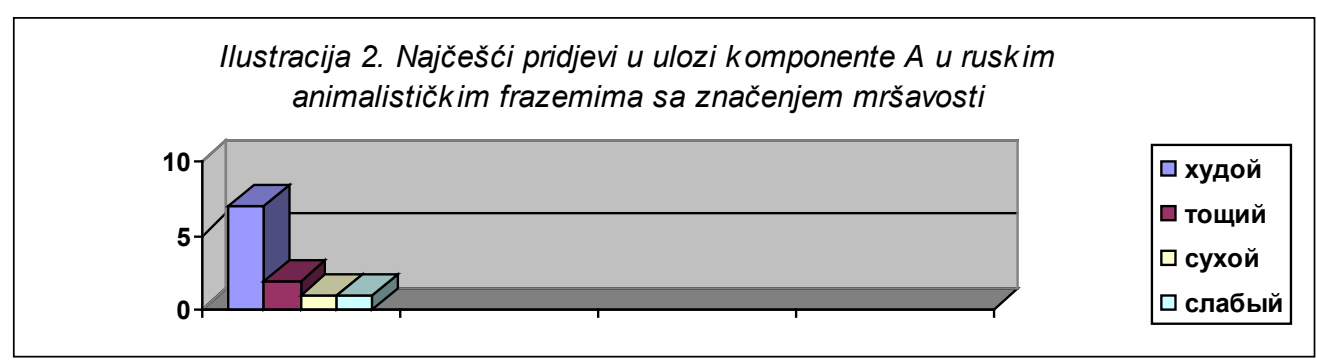

U hrvatskim frazemima o mršavosti najčešće susrećemo pridjeve $m r s ̌ a v$ i suh. Brojnost primjera s navedenim komponentama $\mathrm{A} u$ hrvatskim frazemima prikazana je na Ilustraciji 3.

U slučajevima kad se u ulozi komponente A pojavljuje glagol, u oba jezika nalazimo isti primjer: высохнуть, odnosno osušiti se.

I U ovome su poglavlju ilustrativno prikazani samo oni koncepti unutar kojih nailazimo na barem dva različita oblika komponente $\mathrm{A}$. 
Ilustracija 3. Najčešći pridjevi u ulozi komponente $A$ u hrvatskim animalističkim frazemima sa značenjem mršavosti



\subsubsection{Komponenta $\mathrm{A}$ - vitkost}

Unutar koncepta vitkosti izbor pridjeva u oba je jezika znatno manji. Tako u ruskom jeziku nalazimo pridjev стройная, a u hrvatskome vitka. Važno je napomenuti da je kanonski oblik obaju pridjeva u ženskom rodu, budući da se pozitivno konotirani frazemi s navedenim pridjevima u prvom redu odnose na žensku osobu i koriste za izražavanje komplimenta. Ukoliko se upotrebljavaju oblici muškog roda ovih pridjeva, što je moguće, oni nerijetko dobivaju ironičan ton.

\subsubsection{Komponenta A - debljina}

Želimo li pak osobu usporediti s nekom životinjom zbog njezine debljine, u ruskom ćemo jeziku naići na frazeme s pridjevima толстылй і жирный. (Ilustracija 4.). S druge strane, hrvatska se frazeologija ograničila na pridjev debeo. Kanonski oblik navedenih natuknica u muškome je rodu, osim u frazemu debela kao krava, čija je upotreba ograničena na osobe ženskog spola.

Ilustracija 4. Najčešći pridjevi u ulozi komponente A u ruskim animalističkim frazemima sa značenjem debljine

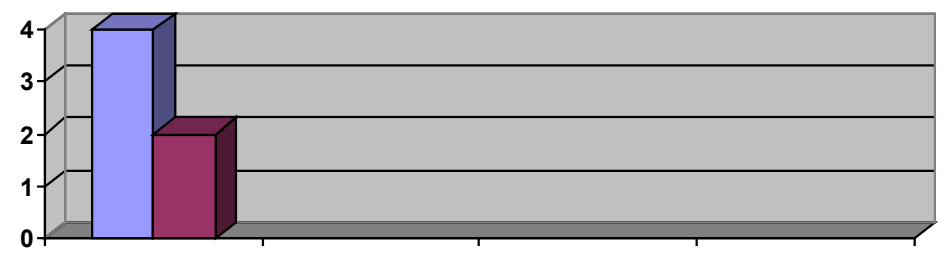

Ruski frazemi glagolskog tipa sadrže glagole разъесться і растолстеть, dok se u hrvatskim primjerima pojavljuju udebljati se i utoviti se.

Kao što je već spomenuto, ruski frazemi sa značenjem debljine jedina su skupina u kojoj nalazimo imenički tip skupa riječi. Pritom se u ulozi komponente A pojavljuje naziv dijela tijela koji je kod debljih osoba povećan - щ̧ёки ('obrazi') i зад ('stražnjica'). 


\title{
3.2. Komponenta $\mathrm{C}$
}

Komponenta $C$ predstavlja pojam s kojim se netko ili nešto uspoređuje. Samim time, izbor, ali i slikovitost komponente $\mathrm{C}$ znatno su širi nego kod prijašnjih komponenti.

Kad je riječ o animalizmima, jasno je da ćemo u sastavu frazema koji ukazuju na koncept mršavosti naići na primjere mršavih životinja. Pritom, one mogu biti ili prirodno mršave ili izgladnjele, no u svakom slučaju pridonose pejorativnoj slici frazema u čijem se sastavu nalaze. Frazemi koji se odnose na vitkost sadrže nazive životinja nešto sitnije, ali zdrave i graciozne građe. Naposljetku, debele se ljude uspoređuje s težim i krupnijim životinjama. U idućim će poglavljima biti prikazano o kojim je konkretno animalizmima riječ, polazeći od koncepta mršavosti, zatim vitkosti te debljine. Primjeri za svaki koncept bit će navedeni gradacijski, od onih u čijemu se sastavu nalazi najjednostavniji životinjski oblik sve do onih najsloženijih. U slučaju postojanja značenjskih ekvivalenata unutar jednoga jezika, primjeri će biti navedeni abecednim redom. Hrvatski ekvivalenti ruskim frazemima bit će prikazani s njihove desne strane.

Svaka će kategorija biti popraćena komentarom o značenju i konotaciji navedenih frazema.

\subsubsection{Koncept mršavosti}

\subsubsection{Ribe}

худой (сухой) как вобла

высохнуть как вобла

худая как селёдка

\author{
mršav (suh) kao bakalar \\ osušiti se kao bakalar \\ suh kao štuka
}

U ruskom se jeziku mršava čovjeka uspoređuje s dvjema vrstama ribe tipičnim za rusko podneblje (s voblom i haringom). Pritom se ne misli na živu ribu nego namirnicu, koja se uglavnom prodaje u sušenom obliku. To potvrđuje i jedini frazem glagolskog tipa u ovoj skupini, koji ukazuje na sam rezultat mršavljenja koji je osobu doveo do te granice da izgledom podsjeća na sušenu voblu. U frazemu худая как селёдка pridjev u ulozi komponente A fiksiran je u ženskome rodu, budući da se uglavnom odnosi na osobe ženskog spola. Slika u navedenom frazemu dobila je i dodatnu konotaciju. Naime, on se pripisuje ne samo mršavoj ženi nego i onoj lišenoj oblina, što je čini manje privlačnom.

Istovjetnu sliku predstavljaju hrvatski ekvivalenti spomenutim ruskim frazemima. Razlika je u tome što se svi hrvatski frazemi mogu odnositi na pripadnike obaju spolova. Usporedba mršavih osoba s bakalarom i štukom uvjetovana je tradicijom. Naime, obje se namirnice u Hrvata jedu u vrijeme posta. Dok je štuka rezervirana uglavnom za kontinentalni dio Hrvatske, bakalar se jede na Badnjak i Veliki petak u cijeloj zemlji. Budući da se ova riba najčešće prodaje u sušenom obliku, jasna je pojava pridjeva suh u spomenutim frazemima (Fink 2002: 38). 
Od svih nabrojenih frazema suh kao štuka daleko se najmanje upotrebljava te polako prelazi u pasivni fond.

\subsubsection{Kolutićavci}

худой (тощий) как глиста

mršav kao glista

Premda se u navedenim frazemima pojavljuje na prvi pogled isti animalizam, njihova je motivacija različita. Naime, u ruskome se jeziku misli na glistu u probavnom traktu. Osim toga, ovaj je frazem dobio i dodatno značenje. Njime se želi reći da je netko mršav, ali i visok. U hrvatskom se jeziku misli upravo na crva ili gujavicu, te se ovaj frazem odnosi na tanašna i slaba čovjeka.

\subsubsection{Kukci}

Navedena kategorija zabilježena je samo u hrvatskome jeziku:

mršav (suh) kao komarac

Frazem se uglavnom odnosi na muškarca, a najčešće se upotrebljava u ironičnom smislu.

\subsubsection{Perad i ptice}

худой (слабый) как воробей (воробышек, воробушек)

тощий как цыплёнок за рубль семьдесят пять

Oba ruska frazema prikazuju malene, slabe ptice na koje izgledom podsjećaju mršavi ljudi. Međutim, u prvom se frazemu misli na živu životinju, dok se drugi odnosi na pileće meso namijenjeno za jelo. Drugi frazem datira iz vremena SSSR-a, kad se za navedeni iznos moglo kupiti najmanje i najlošije pile.

\subsubsection{Sisavci}

$<$ худая> как выдра

худой как ободранная (драная) кошка

худой как уличная (бездомная) собака

mršav kao pas

Prvi frazem pripada razgovornome stilu i odnosi se na mršavu, neprivlačnu žensku osobu. Frazem potječe iz govora Tambovske oblasti, gdje je i sama riječ vidra naziv za bolesna, iznemogla čovjeka, osobito ženu.

U iduća dva frazema čovjeka se poistovjećuje s mačkom i psom. Budući da se navedene životinje ne smatraju prirodno mršavima, u ruskim su frazemima ti pojmovi upotpunjeni epitetima ободранная і драная ('oderana') te уличная і бездомная ('ulična', 'lutalica') da bi se upotpunila slika oslabjele osobe.

Premda animalizam u hrvatskom frazemu mršav kao pas nije upotpunjen nikakvim epitetom (kao što je slučaj s ruskim primjerima), vjerojatno se misli na neishranjenoga psa lutalicu, na kojega podsjeća mršav čovjek. Svi ovi frazemi imaju negativnu konotaciju.

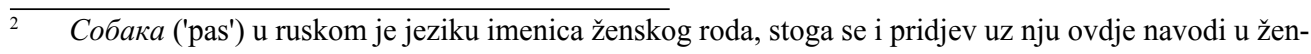
skome rodu. 
Zastupljenost pojedinih životinjskih vrsta u ruskim i hrvatskim animalističkim frazemima unutar koncepta mršavosti prikazana je na Ilustraciji 5 .

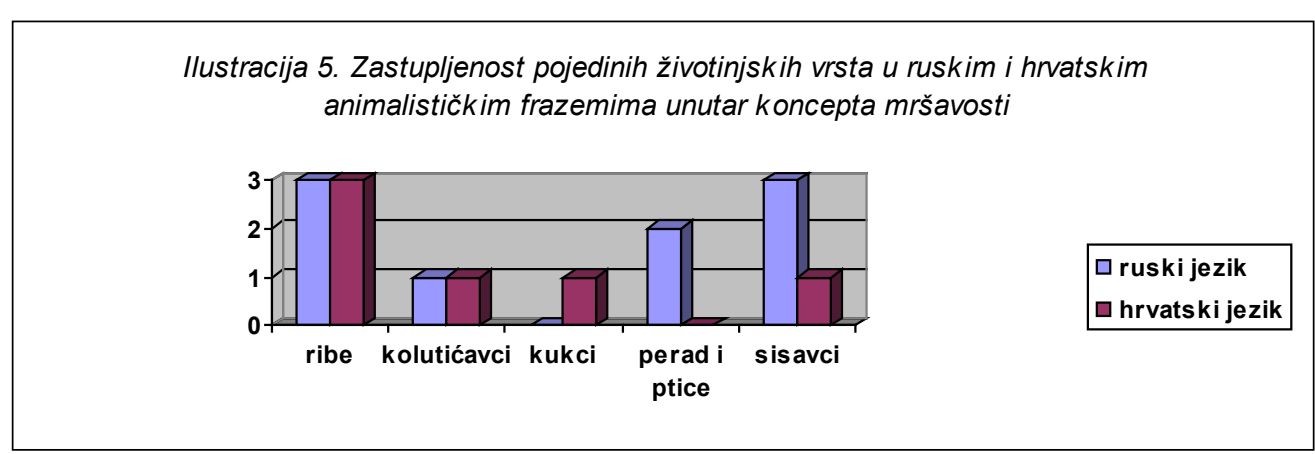

\subsubsection{Koncept vitkosti}

\subsubsection{Sisavci}

U ruskome i hrvatskom jeziku nailazimo na samo jedan primjer frazema s animalizmom:

стройная как серна

vitka kao srna

Navedeni je frazem namijenjen opisivanju ženske osobe, zbog čega je kanonski oblik u ženskom rodu, te ima isključivo pozitivnu konotaciju. Ukoliko se odnosi na muškarca, nosi prizvuk podrugljivosti.

Zastupljenost pojedinih životinjskih vrsta u ruskim i hrvatskim animalističkim frazemima unutar koncepta vitkosti prikazana je na Ilustraciji 6.



\subsubsection{Koncept debljine}

\subsubsection{Perad i ptice}

Ovoj kategoriji pripada samo jedan primjer iz ruskog jezika: жирный как каплун

U spomenutome se frazemu debeo čovjek uspoređuje s pijetlom kojega se tovi radi klanja. 


\title{
3.2.3.2. Sisavci
}

толстый как боров

debeo kao krme разъесться (растолстеть) как боров толстый (жирный) как кабан толстый как поросёнок толстый как свинья

щёки как у хомяка у кого udebljati se (utoviti se) kao prasac (prase) зад как у ломовой лошади у кого

\author{
debeo kao prasac (prase) \\ debeo kao svinja \\ udebljati se (utoviti se) kao svinja
}

debela kao krava

U kategoriji sisavaca naišli smo na najveći broj frazema s kojima se uspoređuju debeli ljudi u ruskome i hrvatskom jeziku. U oba je jezika riječ o snažnim domaćim životinjama koje se obično tove.

Premda svi primjeri nose iznimno negativnu konotaciju, nemaju svi jednaku stilističku obojenost. U ruskom se jeziku prva dva primjera odnose na divlju svinju, te se ne doživljavaju pretjerano uvredljivo. Budući da se u njemu osoba uspoređuje s mladunčetom svinje, ni frazem толстый как поросёнок ne shvaća se iznimno uvredljivim. Navedenim se frazemima želi reći da određena osoba ima problema s težinom, zbog čega je troma i usporena. S druge strane, frazem толстый как свинья nosi jaku negativnu konotaciju. Ne samo da se njime želi nazvati osobu gojaznom, nego i prljavom, imajući u vidu halapljivi način na koji jede.

Hrvatski primjeri imaju sličnu stilističku obojenost. Stoga će i u hrvatskom jeziku frazem debeo kao svinja zvučati najuvredljivije, dok se debeo kao krme i debeo kao prasac (prase) doživljavaju nešto blaže. Navedeni se frazemi koriste jednako za oba spola.

U primjerima frazema glagolskog tipa naglasak je na rezultatu povećanja čovjekove tjelesne mase, zbog čega on izgledom podsjeća na neku od gore spomenutih životinja.

Ruski frazemi щёки как у хомяка у кого і зад как уломовой лошади у кого specifični su utoliko što se ne odnose na čovjeka u potpunosti, nego na određeni dio tijela koji je zbog viška kilograma izraženiji nego što bi trebao biti. Prvi frazem ukazuje na proždrljiva čovjeka, uglavnom muškarca, koji svojim prehrambenim navikama podsjeća na hrčka. Budući da hrčci kraj usta imaju vrećice koje im služe kao spremnici hrane, svaki njezin višak vidljiv je upravo na licu.

Idući frazem odnosi se isključivo na stražnji dio tijela, koji je narastao do te mjere da podsjeća na onaj u teglećega konja. Imajući u vidu ljudsku građu i sklonost nakupljanja kilograma upravo na tome dijelu tijela, jasno je da se navedeni frazem upotrebljava isključivo pri opisivanju ženske osobe.

I hrvatski jezik bilježi jedan primjer koji se uglavnom odnosi na ženu s viškom kilograma (debela kao krava), budući da i animalizam u njegovu sastavu predstavlja životinju ženskoga roda. Navedeni frazem nosi negativnu konotaciju.

Zastupljenost pojedinih životinjskih vrsta u ruskim i hrvatskim animalističkim frazemima unutar koncepta debljine prikazana je na Ilustraciji 7. 
Ilustracija 7. Zastupljenost pojedinih životinjskih vrsta u ruskim i hrvatskim animalističkim frazemima unutar koncepta debljine

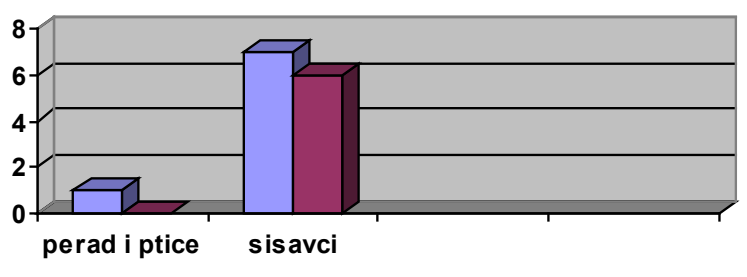

\section{ZAKLJUČAK}

Provedena analiza potvrdila je raznovrsnost animalizama u sastavu ruskih i hrvatskih poredbenih frazema sa značenjem mršavosti, vitkosti i debljine. Prikupljeni korpus sastoji se od 31 frazema i svi oni pripadaju strukturnom tipu skupa riječi. Prema sintaktički glavnoj riječi izdvajamo imenički, glagolski i pridjevski tip, pri čemu je potonji daleko najbrojniji. Semantička analiza korpusa pokazala je da se u ulozi komponente A u ruskom jeziku najčešće nalazi pridjev xydoŭ, a u hrvatskome $m r \check{s} a v$. Vitkost se isključivo izražava pridjevima стройная odnosno vitka, a debljina pridjevima толстьй i debeo. Kanonski je oblik pridjeva uglavnom u muškom rodu, iako se većina frazema odnosi na oba spola. Međutim, u slučajevima kad se određeni frazem odnosi isključivo na ženu, kanonski oblik pridjeva u ženskome je rodu. Analiza komponente $\mathrm{C}$ pokazala je da se mršave ljude uspoređuje s ribama, kolutićavcima, kukcima (samo u hrvatskim primjerima), peradi i pticama (samo u ruskim primjerima) te sisavcima. Premda je njihova uvjetovanost katkad različita, svi ovi frazemi sadrže naziv životinje koja je ili prirodno mršava ili je takva zbog posebnih životnih uvjeta. Neki su frazemi dobili i dodatno značenje te se odnose na mršave osobe koje su usto i prilično visoke ili niske. U frazemima koji se odnose isključivo na žene uz mršavost se nerijetko ukazuje i na nedostatak poželjnih fizičkih atributa.

Vitku se osobu u oba jezika uspoređuje sa srnom. Ovi se frazemi odnose isključivo na ženu i nose pozitivnu konotaciju. Deblji se ljudi samo u ruskim frazemima uspoređuju s peradi i pticama, točnije, s tovljenim pijetlom, dok je u ovoj kategoriji u oba jezika prevlast sisavaca. Nerijetko je riječ o krupnim životinjama za koje se katkad vežu i druge negativne osobine poput lijenosti, tromosti i halapljiva načina hranjenja. Iako ne u jednakoj mjeri, svi frazemi koji ulaze u koncept debljine sa sobom nose negativnu konotaciju.

Animalizmi koji se pojavljuju u ruskim i hrvatskim frazemima uvjetovani su ili geografski ili tradicijsko-kulturološki. 


\section{LITERATURA}

Fink-Arsovski, Željka. 2002. Poredbena frazeologija: pogled izvana i iznutra. Zagreb: FF press.

Melerovič; Mokienko 2005 = Мелерович, Алина М.; Мокиенко, Валерий М. 2005. Фразеологизмы в русской речи. Москва: АСТ - Астрель - Харвест.

\section{RJEČNICI}

Bierich 1997 = Бирих, Александр К. et al. 1997. Словарь фразеологических синонимов русского языка. Ростов-на-Дону: Феникс. [СФСРЯ]

Federov 1995 = Федеров, Александр Ильич. 1995. Фразеологический словарь русского литературного языка кониа XVIII-XX вв., Новосибирск: Наука. [ФСРЛЯ]

Fink-Arsovski, Željka et al. 2006. Hrvatsko-slavenski rječnik poredbenih frazema. Zagreb: Knjigra. [HSRPF]

Korać, Tatjana; Menac, Antica et al. 1979-1980. Русско хорватский или сербский фразеологический словарь / Rusko hrvatski ili srpski frazeološki rječnik. Menac, Antica (red.). sv. I-II. Zagreb: Školska knjiga. [RHSR]

Matešić, Josip. 1982. Frazeološki rječnik hrvatskoga ili srpskog jezika. Zagreb: Školska knjiga. [FRHSJ]

Menac, Antica; Fink-Arsovski, Željka; Venturin, Radomir. 2003. Hrvatski frazeološki rječnik. Zagreb: Naklada Ljevak. [HFR]

Vojnova 1986 = Войнова, Людмила A. et al. 1986. Фразеологический словарь русского языка. Москва: Русский язык. [ФСРЯ]

\section{MREŽNI IZVORI}

Толковый словарь Ожегова. http:// http://dic.academic.ru/

Толковый словарь Ушакова. http:// http://dic.academic.ru/ 


\section{РЕЗЮМЕ}

\section{СЕМАНТИЧЕСКИЙ АНАЛИЗ АНИМАЛИСТИЧЕСКИХ СРАВНИТЕЛЬНЫХ ФРАЗЕОЛОГИЗМОВ СО ЗНАЧЕНИЕМ ХУДОБЫ, СТРОЙНОСТИ И ТОЛЩИНЫ В РУССКОМ И ХОРВАТСКОМ ЯЗЫКАХ}

В данной работе проводится семантический анализ анималистических сравнительных фразеологизмов, которые в русском и хорватском языках указывают на худобу, стройность и толщину человека.

Сначала приводятся общие характеристики сравнительных фразеологизмов, потом определяются наиболее часто встречающиеся структурные типы анималистических сравнительных фразеологизмов, которые входят в концепты худобы, стройности и толщины, а после этого проводится их семантический анализ.

Внутри каждого из данных концептов фразеологизмы классифицированы в соответствии с животным классом, которому принадлежит анимализм в их составе, начиная с самого низшего к тем более сложным. Кроме того, каждый пример совпровождается коментарием об его происхождении и коннотации.

Ключевые слова: русский и хорватский языки, сравнительный фразеологизм, анимализм, худоба, толщина 